\title{
二重相互交配による標準家系の大きさおよび染色体上のマーカーの 間隔が連鎖解析の効率に及ぼす影響
}

\author{
佐藤正賽・古川 力 \\ 農林水産省畜産試験場，茨城県筑波農林研究団地 305-0901
}

(1997.9.9 受付)

\begin{abstract}
要 約 連鎖解析のための標染家系の大きさ招よび染色体上のマーカーの間隔が連銷解析の効率に及 ぼす影響をコンピュータシミュレーションによって調べた。標準家系は二重相互交配によって作成する すのとした，標準家系の大きさの影響を調べるため，以下に示す 3 種類の標装家系を想定した．(1)雄 3 頭䧳 6 頭 ( $\mathrm{P}$ 世代) の交配から各腹雄 1 頭踓 1 10 頭の $F_{1}$ を得る. $F_{1}$ の雌は各腹 8 頭の $F_{2}$ を産する. (2)

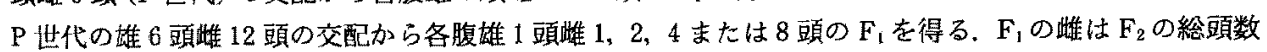

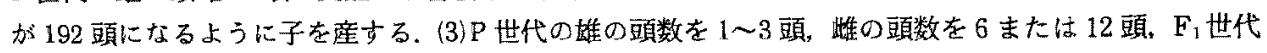
の雄の頭数を 12 または 24 頭とし， $F_{1}$ 世代の崔の頭数を 24 頭に固定し，各腹 8 頭の $\mathrm{F}_{2}$ を産する.いず れの場合も $F_{1}$ の雌は同世代の雄上無作為に交配するものとした。染色体の長さは $1.2 \mathrm{M}$ (モルガン),

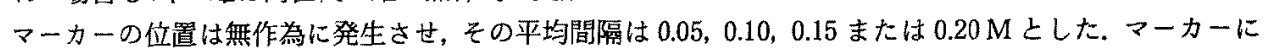
は 2 つの多型を想定し，之の頻度は 0.5 に固定した場合とランダムに発生させた場合の 2 通りを想定し た， $F_{2}$ のマーカーの型を調べることによって, 染色体の長さおよびマーカ一間の連鎖距離を推定すると ともに, ロッドスコア (Z) 扔よび二重へテロの割合等を算出した。 その結果, 標準家系の $\mathrm{F}_{2}$ の頭数は 多いほど連鎖解析の効率は高まるちのの，効率の増加率は減少した，また，マ一力一の平均間隔を短く することによって，染色体の長さの平均二乗誤差およびマーカー間に二重へテロが存在しない割合は必 ずしも减少するとは限らなかった，さらに， $\mathrm{F}_{1}$ 世代の崔の頭数 $\left(\mathrm{F}_{2}\right.$ の頭数)を一定にした場合，P 世代 の蜼雄頭数や $F_{1}$ 世代の雄の頭数が多いほどわずかながら連鎖解析の效率は高まった。
\end{abstract}

日畜会報，69(2)：126-132，1998

既知の遗伝子やDNA マーカー（以下、マーカー）に よって主㗢遗伀子等の位置を同定するための方法として 遺伝連鎖地図の利用がある。精密な遗伝連鎖地図を作製 するためには，まずマーカー間の連鎖解析を効率的にす すめる必要がある ${ }^{12)}$ 、マーカーの連鎖解析の効率は, 連 鎖距離，対立遣伝子数やマーカーの多型数とその頻度， 浸透度 (penetrance)，連銷不平衡の程度等の様々な要 因によって影響される゙,6,8)．家畜等では，連鎖地図を効 率的に作製するととるに主働道伀子をはじめとする QTLs（量的形質関連遗伝子群）の位置を同定するため の1つの手法として，標準家系 (reference family) を作 成し，これに基づいた連銷解析が行わ扎ている1-8,99.

棌染家系による連鎖解析は，品種あるいは種 (P世代) 間等の $F_{1}$ 同士あるいは戻し交配から得られる子の遗伝 子あるいはマーカ一等の型(以下これらをまとめて遗
伝子型とする）に基づいて行われており，家系のサイズ が大きいほど正確な連鎖解析が見込まれる。しかし，標 準家系は能力が極端に異なる特殊な品種等の組み合せを 用いることが多いため，一般に実験的に作成されること が多い，このような状況下では，標準家系の大きさは作 成経費や労力等の面から制約を受忛るため，状況心応じ た大きさを考える必要がある.

標準家系は，コスト，学力，施設等による制約から， 主として $\mathrm{F}_{1}$ 世代の雌粯の頭数あるいは $\mathrm{F}_{2}$ 世代の頭数に 制約を受けることが多い，一方，P世代の雌雄頭数や $F_{1}$ 世代の雄の頭数む連鎖解析の効率に影響を与える可能性 がある．また，マーカーが多いほど連銷解析の効率は高 まることが予想される反面，連銷解析に要するコストや 学力等它增大する，そのため，染色体上に配置される マーカーの平均間隔 (マーカーの個数) が連鎖解析の効 
率に与える影響を調べることで，より效率的な実験計画 が構筑できる．連鎖解析において効率的な実験計画を構 築するための研究は少なく占,13)，このための標準家系の 作成法に関する研究はなされていない。

そこで本研究は，P世代および $F_{1}$ 世代の集団の大き さおよびマーカーの平均間滆が連鎖解析の勃率に及ば す影響を，二重相互交配からなる標準家系を想定したコ ンピュータシミュレーションによって明らかにすること を目的とした.

\section{方法}

標準家系の大きさおょびマーカーの平均間隔が連鎖解 析の効率に与える影響を明らかにするため，買なる $2 つ$ の集団の二重相互交配に上る標準家系を想定し，標準家 系の各個体の遺伝子型をモンテカルロ法によるコン ピュータシミュレーションにより発生させた．標準家系 の基礎となる 2 品種（集団）の一方を雄家系, 他方を崔 家系とする。

(1) $F_{1}$ 世代の倠の頭数（F 世代の頭数；NDとする） 之連鎖解析の効率之の関係を調べるため, 雄家系から雄

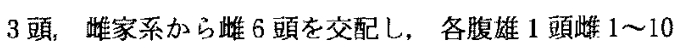
頭 (複数の産次や受精卵移植等により得るものとする), 合計雄 6 頭雌 $6 \sim 60$ 頭の $F_{1}$ からなる 10 通りの標準家系 を発生させた． $F_{1}$ の雌は同世代の雄と無作為に交配し， 各腹 8 頭の $\mathrm{F}_{2}$ を産するものとした。
（2） $\mathrm{F}_{2}$ 世代の総頭数を一定としたときの $F_{1}$ 世代の雌 の頭数（一腹あたりの子の頭数）之連鎖解析の効率との 関係を調べるために, 雄家系から雄 6 頭, 催家系から雌 12 頭を交配し，各腹雄 1 頭雌 $1 ， 2 ， 4$ または 8 頭, 合計 雄 12 頭倠 $12,24 ４ 8$ または 96 頭の $F_{1}$ を得るすのとし

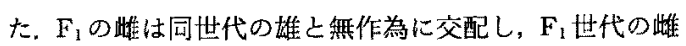
の頭数のそれぞれに対してその子の頭数を $16 ， 8 ， 4 ， 2$ 頭之なるような標準家系を発生させた $\left(\mathrm{F}_{2}\right.$ 世代の総頭数 はいずれも 192 頭)。

(3) P 世代の雌雄頭数（それぞれ NGS，NGD とする) および $\mathrm{F}_{1}$ 世代の雄の頭数 (NS とする) と連鎖解析の効 率との関係を調べるため, P 世代の雄の頭数を 1 ～頭, 雌の頭数を 6 または 12 頭， $F_{1}$ 世代の雄の頭数を 12 また は 24 頭とし， F 1 世代の䧼の頭数を 24 頭に固定した標準 家系を発生させた， $F_{1}$ の雌法同世代の雄之無作為に交配 し，各腹 8 頭の $\mathrm{F}_{2}$ を産するすのとした．

マーカーはすべて共優性を示す 2 つの逪伝子型がみら れ，2 個のマーカーは染色体上の両端に位置するすの之 した，染色体の長さは $1.2 \mathrm{M}$ (モルガン) とし，両端の マーカー以外は染色体上に無作為に配置され，その平均 間隔は $0.05,0.10,0.15,0.20 \mathrm{M}$ の 4 通りを想定した. 遺 伝子型の頻度は理想的な頻度として 0.5 に固定した場合 （ケース1）と，P世代のそれぞれの集団に打いてマー カーごとに 0 加ら1の一様乱数により無作為に発生させ る場合 (ケース2)の 2 通りを想定した. 連鎖解析では可
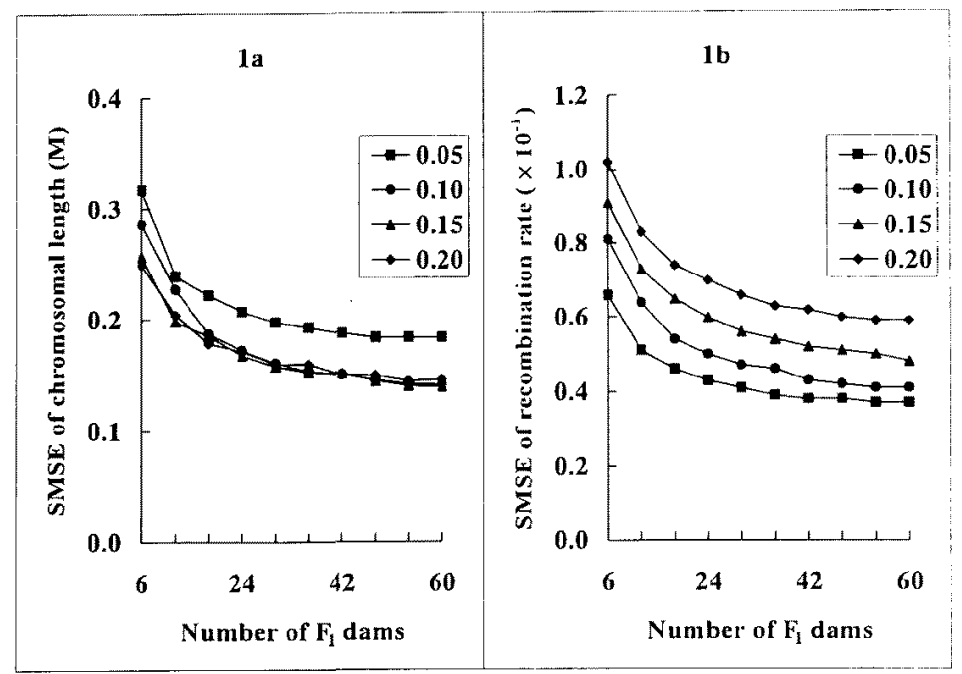

Fig. 1. Square root of mean square error (SMSE) of chromosomal length (1 a) and SMSE of recombination rate between markers $(1 \mathrm{~b})$ with different number of $F_{1}$ dams. Figures in the legends indicate average interval of markers $(\mathbf{M})$ on a chromosome. 
能な限り理想的な頻度に近いマーカーが選定されるた め，実際の標準家系で用いられるマーカ一の頻度はケ一 ス1とケース2の開にあると考えられる(1).また，マー 力一の染色体上の位置は標準家系ごとに異なるものと し, 位置の俱なるマーカーを20標準家系分発生させ, 各 家系内で 50 反復のデー夕を発生させた.

コンピュータシミュレーションにより発生させた道伝 子型から，染色体の長さ拉よびマ一カー間の組換率の平 均二乘誤差の平方根（SMSE）を算出するとともに, マーカー間のロッドスコア $(2 \text { 值 })^{7)}$ を算出し, 連鎖解析 の効率の指標之した。なる。值は，世代P の造伝子型を
調べ， $F_{1}$ の相が判明する場合には 3 世代の家系情報によ る連銧解析から， $\mathrm{F}_{1}$ の相が判明しない場合には 2 世代の 家系情報に上る連鎖解析加ら算出した。

標滸家系の $\mathrm{F}_{1}$ 世代の染色体上で隣接したマーカー間 に二重へテロが全く存在しない場合には，組換率は推定 できないものとして除いた。また，隣接したマーカ一間 の組換率が 1 箇所でも推定できない場合には，染色体の 長さは推定できないものとした。

\section{結果および考察}

F、世代の ND と染色体の長さの SMSE, 枋よびマー

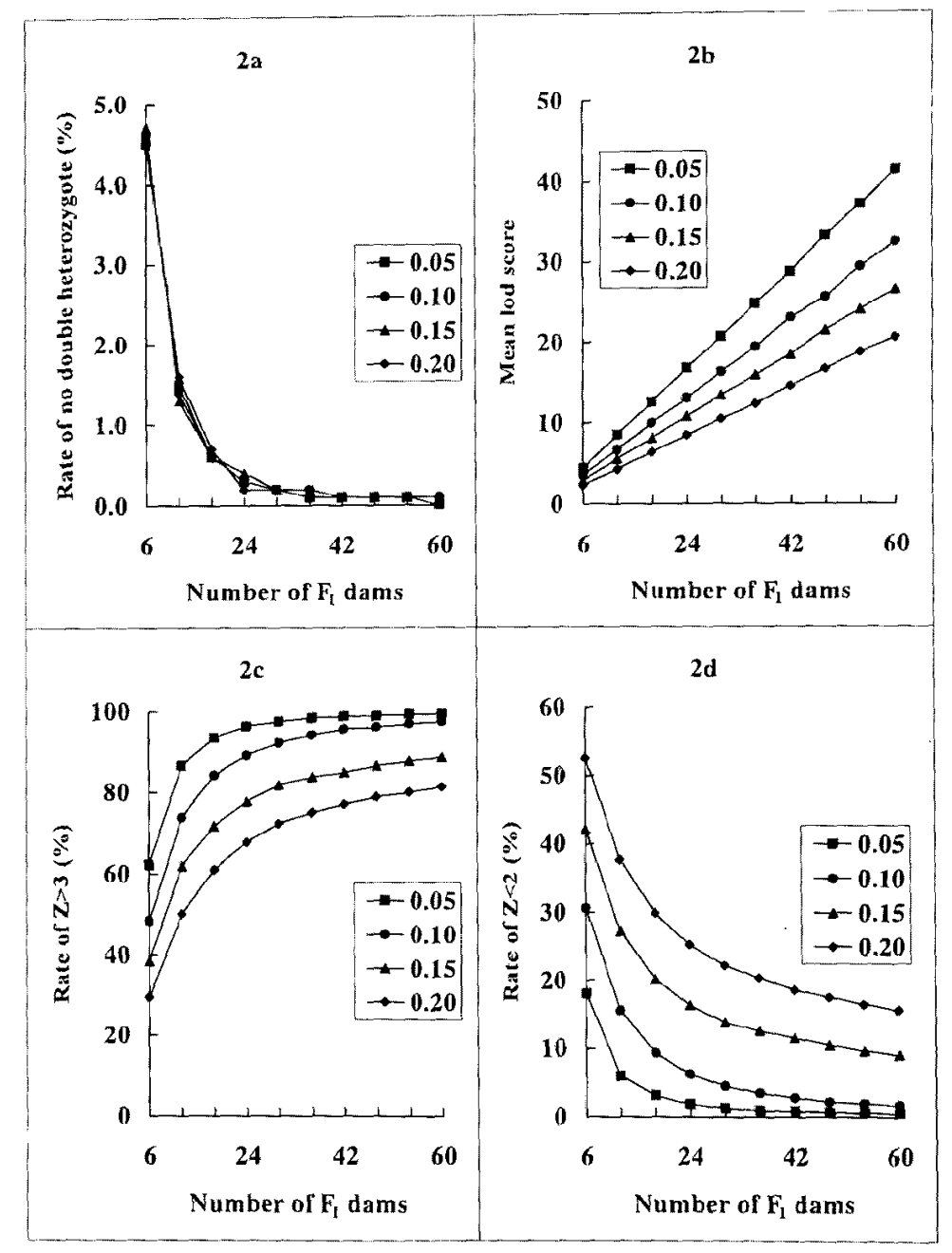

Fig. 2. Rate of no double heterozygote in a reference population (2a), mean lod score (2 b), and rate of $Z>3(2 \mathrm{c})$ and rate of $Z<2(2 \mathrm{~d})$ for linkage between markers with different number of $F_{1}$ dams. Figures in the legends indicate average interval of markers $(M)$ on a chromosome. 
カー間の組換率のSMSE との関係を図1に示した. 図1 はヶース10場合について示したが，ケース20場合も ケース 1 と同様の傾向がみられた. NDが多くなるほよ゙ 染色体の長さおよびマーカ一間の組換率における SMSE は小さくなった。 しかし，両者のSMSE の減少 率は ND が多くなるほよ゙小さくなった。染色体の長さの SMSE は, ND肪 18 頭以上でマ一カ一の平均間隔が $0.10 \mathrm{M}$ 以上の場合にはマーカーの平均間隔に影響され なかった，一方，マーカー間の組換率のSMSE はマー カーの平均間隔が短いほど小さい値となった。

$\mathrm{ND}$ と，標準家系の中に二重へテロが全く存在しない 割合，全マーカーの平均 Z 值， Z 值が 3 を越える割合。 抢上びZ値が 2 末満の割合を図 2 に示した。図 1 上同様 の理由加，図2もケース1の場合についてのみ示し た. 標準家系の中に二重へテロが全く存在しない割合 は, マーカーの平均間隔とは無関係に NDが多くなるほ ど減少し，NDが 24 頭を越えるとほぼ横ばいとなった。 全マーカーの平均 $Z$ 值は, $N D$ が多くなるにつれて直線 的に増加した，Z值が 3 を越える割合は，NDが多くな るにつれて高くなるものの，その増加率は減少した。ま た, マーカーの平均間隔が短いにど早く上限に達する傾 向にあった。 Z 值が 2 末満の割合は，Z值が 3 を越える 割合とは逆の傾向がみられた，すなわち，NDが多くな るにつれて低くなるものの，その減少率は小さくなっ
た。また、マーカーの平均間櫺が短いほど早く下限に達 する傾向にあった。

図 1 は連鎖地図を作成する上で，NDがマーカ一間の 距離の推定精度に与える影響を示している，一方，図 2 はNDがマーカー間の検定効率に与える影響を示して いる．予想された通り，いずれの場合に扔いてもNDが 多いはよ゙,す极わち $\mathrm{F}_{2}$ の数が多いほど連鎖解析の初率 は高まることが示された。.しかし，NDと連鎖解析の効 率は線形関係にはなく，ND が多くなるはど効率の堌加 率は減少傾向にあった。 また, マーカーの平均間隔と連 鎖解析の効率す同様に，線形関係にはない場合がみられ た. すなわち, NDゃマーカーの数を多くしてを，それに 㒻合うだけの高い効率が得られるとは限らないことが明 らかとなった，標準家系老作成し，これに基づいて連銷 解析をすすめる場合，コスト，労力，施設等による制約 から，主としてND (あるいは $\mathrm{F}_{2}$ の数) とマーカーの数 が制限されることが多いが，特にNDは最す大きな制約 条件の1つである，本研究の結果は, 連鎖解析の効率に は上限があり，ND在要以上に多くしても効辫は高ま らないことを示している。

$\mathrm{F}_{2}$ 甘代の総頭数を一定としたときのND（または一腹 あたりの子の頭数)とマーカー間の組換率の平均二乗䛊 差, マーカー間に二重へテロが存在しない割合および平 均 Z值との関係を表 1 に示した. マーカー間の組換率の

Table 1. Square root of mean square error of recombination rate between markers (A), rate of no double heterozygote between markers (B) and mean lod score (C) in a reference population with different number of $F_{1}$ dams with constant number of $F_{2}$ animals

\begin{tabular}{|c|c|c|c|c|c|c|}
\hline \multirow{2}{*}{$\begin{array}{l}\text { Criteria of } \\
\text { efficiency }\end{array}$} & \multirow{2}{*}{$\begin{array}{l}\text { Number } \\
\text { of dams }\end{array}$} & \multirow{2}{*}{$\begin{array}{c}\text { Number of } \\
\text { progenies } \\
\text { per dam }\end{array}$} & \multicolumn{4}{|c|}{ Average interval between markers (M) } \\
\hline & & & 0.05 & 0.10 & 0.15 & 0.20 \\
\hline \multirow[t]{4}{*}{ (A) } & 12 & 16 & $5.4^{\mathrm{a})}$ & 4.0 & 5.3 & 6.6 \\
\hline & 24 & 8 & 4. 4 & 4.3 & 5.0 & 6.4 \\
\hline & 48 & 4 & 4. 2 & 4.7 & 5.2 & 5.6 \\
\hline & 96 & 2 & 5.2 & 4.6 & 5.2 & 6.3 \\
\hline \multirow[t]{4}{*}{ (B) } & 12 & 16 & 4. $8^{\mathrm{b}\rangle}$ & 4.5 & 3.7 & 6.5 \\
\hline & 24 & 8 & 3.4 & 2.9 & 2.6 & 3.0 \\
\hline & 48 & 4 & 2.3 & 2.4 & 3.9 & 1.6 \\
\hline & 96 & 2 & 2. 1 & 2.8 & 1.7 & 1. 4 \\
\hline \multirow[t]{4}{*}{ (C) } & 12 & 16 & 15.5 & 12.3 & 10.3 & 8. 1 \\
\hline & 24 & 8 & 15.4 & 12.3 & 10.3 & 8. 2 \\
\hline & 48 & 4 & 14.4 & 11.8 & 8.8 & 6.8 \\
\hline & 96 & 2 & 14.9 & 11.9 & 9.8 & 8.0 \\
\hline
\end{tabular}

a) Unit is centi morgan.

b) Unit is percent. 
佐藤・古川

平均二乗誤差と NDとの間に顕著な差は認められな 加った。 マーカー間に二重へテロが存在し极い割合は NDが多くなるほど低くなる傾向にあったが，これは NDが多け机ば二重へテロが存在する確率が增加するた めである. 一方，平均 Z 值はNDが多くなるほど小さく なる傾问がみら机たが，これらの差は小さいものであっ た．以上のこと加ら， $F_{2}$ 世代の総頭数を一定としたとき の ND の影響は小さいむのであると考えられた.

NGS, NGD およびNSは, NDのように連銷解析の効 率に大きな影響を及ぼすむのではなかった。しかしこ れらの影響が無視できないものとして，標準家系の中に 二重へテロが全く存在しない割合招よび染色体の長さが 推定できない割合があげられた（表 2)。ケース 2 は染色
体の長さが推定できない割合において，ケース1よりも NGS や NGD 等の頭数の違いによる影響が顕著に表れ たため，表 2 はケース2についてこれらの関係を示し た.

標準家系の中に二重へテロが全く存在しない割合は, NGS，NGD，NSがそれぞれ多いほど低くなった，標準 家系を棈成する頭数が最も少ない場合（NGS $=1, N G D$ $=6, \mathrm{NS}=12)$ は，それが最も多い場合（NGS=3，NGD $=12, \mathrm{NS}=24)$ に比へて 3 倍前後の値となった．染色体 の長さが推定できない割合も，NGS，NGD，NSがそれ ぞれ多いほど低くなった，標準家系を構成する頭数が最 も少ない場合は，そ执が最も多い場合に比べて $30 \%$ 前 後の差がみられた。このことが生じた原因として，GS

Table 2. Rate of no double heterozygote beiween markers (above) and rate of unestimable chromosomal map length (below) in a reference population with different number of grandsires and grandams (males and females of initial generation) and sires (males of $F_{1}$ )

\begin{tabular}{|c|c|c|c|c|c|c|}
\hline \multirow{2}{*}{$\begin{array}{l}\text { Number of } \\
\text { grandsires }\end{array}$} & \multirow{2}{*}{$\begin{array}{c}\text { Number of } \\
\text { grandams }\end{array}$} & \multirow{2}{*}{$\begin{array}{c}\text { Number of } \\
\text { sires }\end{array}$} & \multicolumn{4}{|c|}{ Average interval between markers (M) } \\
\hline & & & 0.05 & 0.10 & 0.15 & 0.20 \\
\hline \multirow[t]{4}{*}{1} & 6 & 12 & $13.04^{a)}$ & 9.89 & 12.31 & 15.70 \\
\hline & & 24 & 12.14 & 9.44 & 11.51 & 14.40 \\
\hline & 12 & 12 & 10.13 & 7.40 & 8.85 & 10.87 \\
\hline & & 24 & 8.82 & 6.01 & 8.08 & 9.82 \\
\hline \multirow[t]{4}{*}{2} & 6 & 12 & 9.19 & 6.72 & 7.70 & 11.57 \\
\hline & & 24 & 8.44 & 6.50 & 7.47 & 9.67 \\
\hline & 12 & 12 & 6.88 & 4.09 & 5.20 & 6.78 \\
\hline & & 24 & 6.18 & 3.45 & 5.41 & 6.42 \\
\hline \multirow[t]{4}{*}{3} & 6 & 12 & 7.66 & 5.70 & 5.79 & 8.77 \\
\hline & & 24 & 7.06 & 4.95 & 5.46 & 8.63 \\
\hline & 12 & 12 & 5.68 & 3.53 & 4.25 & 6. 35 \\
\hline & & 24 & 4.99 & 2.80 & 3.93 & 5.67 \\
\hline \multirow[t]{4}{*}{1} & 6 & 12 & $88.6^{a}$ & 55.1 & 48.0 & 49.1 \\
\hline & & 24 & 87.3 & 53.2 & 47.1 & 46.1 \\
\hline & 12 & 12 & 81.9 & 49.5 & 40.0 & 37.9 \\
\hline & & 24 & 77.0 & 42.0 & 37.4 & 35.0 \\
\hline \multirow[t]{4}{*}{2} & 6 & 12 & 78.6 & 42.5 & 34.5 & 38.1 \\
\hline & & 24 & 75.8 & 42.2 & 33.1 & 35.3 \\
\hline & 12 & 12 & 71.8 & 30.0 & 26.9 & 26.3 \\
\hline & & 24 & 65.6 & 25.8 & 26.4 & 25.2 \\
\hline \multirow[t]{4}{*}{3} & 6 & 12 & 74.8 & 39.0 & 28.1 & 31.5 \\
\hline & & 24 & 68.8 & 36.1 & 26.6 & 30.2 \\
\hline & 12 & 12 & 63.3 & 28.9 & 22.5 & 23.8 \\
\hline & & 24 & 57.4 & 22.0 & 20.3 & 22. 0 \\
\hline
\end{tabular}

a) Unit is percent. 
やGDの数が少ない場合，標準家系内に二重へテロが存 在する確率は，それが多い場合に比べて小さくなるため と考えられる。標準家系を作成するにあたり，NGS， NGD およびNSを壃やすことはND老增やす場合に比 べて比較的容易である，したがって，NGS，NGD および NS を増やすことは連鎖解析の効率を䯩める上で有用で あると結論づけた。

本研究では隣接したマーカー間に二重へテロが存在し ない場合，そのマーカー間の位嘪関係は不明であるとし ているが，実際には複数のマーカーを同時に連鎖解析す ること（multipoint linkage analysis）肪可能である. この方法を用いればマーカーの位㯰関係が判明する可能 性は高まると考えられる，例えば，マーカーの平均間隐 が短ければ，隣接するマーカ一間に二重へテロが存在し なくてb，次に隣接するマ一カーを利用してマーカーの

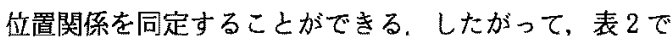
はマーカーの平均間谝が $0.10 \mathrm{M} や 0.15 \mathrm{M} よ り あ 0.05 \mathrm{M}$ のほうが染色体の長さの推定が困嚾であるように見受け られるが, multipoint linkage analysisにより，マー カーの平均間隔が短いほど染色体の長さの推定の可能性 は高まると考えられる、しかし、マーカーの平均間隔が 長い場合, 例えばそれが $0.20 \mathrm{M}$ の場合に隣接するマー カーの位置関係が不明であれば，次の隣接マーカーまで の距離は平均的に $0.40 \mathrm{M}$ となる。したがって, マーカー の平均間隔が長い場合には，標準家系が大きなものでな ければマーカーの位直関係を同定することは困蜼にな る.

本研究および効率的に連鎖解析を行うための標潮家系 の作成に関する一連の研究結果 ${ }^{10,11}$ 加ら，標準家系に用 いる集団の連鎖不平衡の程度, 標準家系内の交配方法, 標準家系の大きさ，染色体上のマーカーの平均間隔等の 影響が明らかとなった。 しかし，マーカーの多型数とそ の頻度，マーカーの間潭のばらつきの程度による影響等 についても今後検討する必要があると考える。

\section{文献}

1) Archibald AL, Haley CS, Anderson L, Bosma AA, Dacies W, Fredholm M, Geldermann $\mathbf{H}$, Gellin J, Groenen M, Gustavsson I, Ollivier L, Tucker EM, Van de Weghe A. PiGMaP:An European initiative to map the porcine genome. Anim. Genet., 22 : (suppl. 1) 82-83. 1991.

2) Archibald AL, Haley CS, Brown JF, Couperwhite S, McQueen HA, Nicholson, D, Coppieters W, Van de Weghe A, Stratil A, Winterø AK, Fredholm M, Larsen $N J$, Nielsen
VH, Milan D, Woloszyn N, Robic A, Dalens $M$, Riquet J, Gellin J, Caritez JC, Burgaud G, Ollivier L, Bidanel JP, Vaiman M, Renard C, Geldermann H, Davoli R, Ruyter D, Verstege EJM, Groenen MAM, Davies W, Høyheim B, Keiserud A, Andersson L, Ellegren $H$, Johansson M, Marklund L, Miller JR, Anderson Dear DV, Signer E, Jeffreys AJ, Moran C, Le Tissier P, Muladno, Rothschild MF, Tuggle CK, Vaske D, Helm J, Liu HC, Rahman A, Yu TP, Larson RG, Schmitz CB. The PiGMaP consortium linkage map of the pig (Sus scrofa). Mamm. Genome, $6: 157-175$. 1995.

3) Bishop MD, Kappes SM, Keele JW, Stone RT, Sunden SLF, Hawkins GA, Toldo SS, Fries R, Grosz MD, Yoo J, Beattie CW. A genetic linkage map for cattle. Genetics, $136: 619-639.1994$.

4) Botstein D, White RL, Skolnick M, Davis W. Construction of a genetic linkage map in man using restriction fragment length polymorphisms. Am. J. Hum. Genet., 32 : 314-331. 1980.

5) Elsen JM, Mangin B, Goffinet B, Chevalet C. Optimal structure of protocol designs for building genetic linkage maps in livestock. Theor. Appl. Genet., 88 : 129-134. 1994.

6) Geldermann H. Mapping quantitative traits by means of genetic markers. Proc. 4th World Congr. Genet. Appl. Livestock Prod., 13 : $97-$ 106. 1990 .

7) Morton NE. Sequential tests for the detection of linkage. Am. J. Hum. Genet., $7: 277-318$. 1955.

8) Ott J. Analysis of human genetic linkage. lst ed. 54-107. The Johns Hopkins Univ. Press. London. 1991.

9) Rohrer GA, Alexander LJ, Keele JW, Smith TP. A microsatellite linkage map of the porcine genome. Genetics, $136: 231-245.1994$.

10）佐藤正莧・古川 力. 連鎖不平衡が連鎖解析の効 率に及ぼす影響。日畜会郝，68：956-964。1997。

11）佐藤正賀・古川 力. 二重相互交配による標準家 系の $\mathrm{F}_{1}$ 世代の交配方法が連鎖解析の効率に及法 す影響. 日畜会報, 69:26-31. 1998.

12) Smith $\mathrm{C}, \mathrm{Smith} \mathrm{DB}$. The need for close linkages in marker-assisted selection for economic merit in livestock. Anim. Breed. Abst., 61 : 197204. 1994.

13) Van der Beek S, van Arendonk JAM. Criteria to optimize designs for detection and estimation of linkage between marker loci from segregating populations containing several families. Theor. Appl. Genet., 86 : 269-280. 1993. 
佐藤・古川

\title{
Effects of Population Size and Marker Interval on Efficiency of Constructing a Genetic Linkage Map Using Reference Family from Intercross
}

\author{
Masahiro SATOH and Tsutomu FURUKAWA \\ National Institute of Animal Industry, Tsukuba Norin Kenkyu Danchi, \\ Ibaraki-ken 305-0901
}

\begin{abstract}
Effects of population size, and interval of markers on a chromosome in reference family on the efficiency of linkage analysis was studied using computer simulation. The genetic linkage map was constructed using a two generation reference population of intercross. Three types of reference populations were used for investigating the effect of reference population size : The first comprised $6 F_{1}$ sires and 10 different numbers of $F_{1}$ dams (6 to 60 ) derived from a cross between three grandsires from a different breed with six grandams from another breed. Each $F_{1}$ dam produced eight progenies. The second comprised $12 F_{1}$ sires and $12,24,48$ or $96 F_{1}$ dams derived from a cross between six grandsires and 12 grandams. $F_{1}$ dams produced $192 F_{2}$ progenies altogether. The third comprised $24 F_{1}$ dams and 12 or $24 F_{1}$ sires derived from a cross between 1 , 2 or 3 grandsires and 6 or 12 grandams and each $F_{1}$ dam produced eight progenies. All $F_{1}$ dams were mated randomly to each type of $F_{1}$ sires from reference population. Chromosomal map length of 1.2 Morgans, and an average interval between markers of $0.05,0.10,0.15$ or 0.20 Morgans on a chromosome and two alleles of markers were assumed. The considered markers were placed at random intervals on a chromosome. Chromosomal map length and recombination rate between markers with the lod scores $(Z)$ were estimated using genotypic data from the reference population. Efficiency of linkage analysis increased consistently, but the rate declined steadily as the number of $F_{2}$ animals increased. The shortest average interval between markers was not always the best efficiency for mean square error of chromosomal length and rate of no double heterozygote between markers. The efficiency of linkage analysis increased slightly as the number of grandparents and $F_{1}$ sires increased when number of $F_{1}$ dams $\left(F_{2}\right.$ animals) was kept constant.
\end{abstract}

Anim. Sci. Technol. (Jpn.) 69 (2) : 126-132, 1998

Key words : Linkage analysis, Population size, Interval of markers, DNA markers 